\title{
Yield potential and fruit quality of scallop squash (Cucurbita pepo L. var. patissonina Greb. f. radiata Nois.) cultivars grown for processing
}

\author{
Eugeniusz Kołota*, Agnieszka Balbierz \\ Department of Horticulture, Wrocław University of Environmental and Life Sciences, pl. Grunwaldzki 24a, 50-363 Wrocław, Poland
}

\begin{abstract}
Scallop squash fruits may be harvested at different stages of development. Small size fruits, intended both for the fresh market and the food industry, have the highest biological value. This study was conducted to determine the yield potential of scallop squash cultivars ('Polo F1', 'Disco', 'Gagat', 'Okra', 'Sunny Delight F1') grown on mulched (black polyethylene foil or black agrotextile) or unmulched soil, and harvested when fruits reached a diameter of 3-6 cm. Based on 3-year average data, the highest marketable and early yield was produced by 'Sunny Delight F1'. This cultivar is also appreciated by consumers for its yellow colored skin of fruits. Another advantage of this cultivar was its high nutritional value expressed by the highest content of dry matter, vitamin $\mathrm{C}$, polyphenols and minerals ( $\mathrm{K}, \mathrm{P}, \mathrm{Ca}, \mathrm{Mg}$ ), with limited tendency to nitrate accumulation. Among the other cultivars tested, 'Okra' showed high yield potential, 'Gagat' was a rich source of carotenoids, and 'Disco' polyphenols. Black polyethylene foil and black agrotextile appeared to be equally effective mulching materials. The benefit from the application of mulch was a significant increase in yield without any change in the chemical composition of the fruit.
\end{abstract}

Keywords: synthetic soil mulches; fruit chemical composition

\section{Introduction}

Scallop squash (Cucurbita pepo L. var. patissonia Greb. f. radiata Nois., Cucurbitaceae), like zucchini, belongs to the group of summer squashes which most commonly are harvested and eaten at an immature stage when the rinds are still soft. Scallop squash fruits are flat, rounded and scalloped with various colors of skin. If harvested at full maturity, scallop squash can reach a diameter of about $20 \mathrm{~cm}$ and a weight of $1.5-2.0 \mathrm{~kg}$. Mature squash can be stored for 2-3 months and supplied to the market outside the growing season [1-3]. Immature fruits, which have a limited storage life potential, are supplied to the fresh market or used for processing, mainly for canning, freezing or dehydration [4]. Such fruits are harvested before the skin begins to harden, when they reach a diameter of $3-6 \mathrm{~cm}$, and are used for processing or 6-12 $\mathrm{cm}$ diameter fruits are supplied to the fresh market. Sometimes, the male and female yellow flowers may be collected and used for consumption as a kind of special food, either alone or as a colorful addition to salads. The flowers are considered to be a valuable source of dietary and biologically active compounds $[4,5]$.

\footnotetext{
* Corresponding author. Email: eugeniusz.kolota@up.wroc.pl
}

Handling Editor: Elżbieta Weryszko-Chmielewska
Summer squashes, including scallop, are low in energy value and highly appreciated for high contents of minerals such as potassium, magnesium, calcium and iron, vitamin B complex, ascorbic acid, and carotenoids. The nutritional value of scallop squash is higher than cucumber due to its higher level of protein, vitamin $C$ and carotenoids [6,7] and low tendency to accumulate nitrates or heavy metals $[2,8]$. Immature small squash fruits are a richer source of macroand micronutrients, sugars, protein and vitamin $\mathrm{C}$, compared to fruits harvested at the later stages of development $[9,10]$.

Scallop squash is mainly a seed propagated minor crop in Central European countries, where it is commonly grown in home gardens. In the last few years, however, a growing interest has been observed in using small fruits for processing. Beside its high nutritional value, another advantage of scallop squash is that it has moderate soil nutrient and moisture requirements and better tolerance of low temperatures than the other species from the Cucurbitaceae family.

The objective of the study was to evaluate the fruit value (dry matter content, total sugars, vitamin C, carotenoids, total polyphenols, $\mathrm{P}, \mathrm{Mg}, \mathrm{Ca}, \mathrm{K}$, and nitrates) in five scallop squash cultivars included in the Polish National List of Vegetable Plant Varieties [11] and grown on mulched and unmulched soils for harvest of small size fruits suitable for processing. Black polyethylene foil and black agrotextile, which are the most common materials for weed control in vegetable crop production, were used in the experiment. 


\section{Material and methods}

A field study was conducted in 2011-2013 at the Piastów Horticultural Research Station, near Wrocław (long. 17.00 E, lat. $51.05 \mathrm{~N}$ ), on a sandy clay soil with $1.8 \%$ organic matter and $\mathrm{pH}$ in $\mathrm{H}_{2} \mathrm{O}$ of 7.1 The soil content of available forms of phosphorus was $55-64 \mathrm{mg} \mathrm{dm}^{-3}, 50-68 \mathrm{mg} \mathrm{dm}^{-3}$ of potassium, and $20-30 \mathrm{mg} \mathrm{dm}^{-3}$ of mineral nitrogen $\left(\mathrm{NH}_{4}-\mathrm{N}+\right.$ $\mathrm{NO}_{3}-\mathrm{N}$ ), depending on the year of the study. Scallop squash was cultivated at the standard level of phosphorus and potassium available forms $-80 \mathrm{mg} P$ and $200 \mathrm{mg} \mathrm{K}$ per $1 \mathrm{dm}^{3}$ of soil. The required doses of these nutrients were established on the basis of annual chemical analysis of soil samples and applied in the form of triple superphosphate and potassium sulphate 3-4 days before planting and mixed with the soil by harrowing. Nitrogen in the form of ammonium nitrate was used as a single preplant dose in the amount of $120 \mathrm{~kg} \mathrm{~N} \mathrm{ha}^{-1}$.

The experiment comprised five cultivars of scallop squash developed by the Polish breeders ('Polo F1', 'Disco', 'Gagat', 'Okra') and 'Sunny Delight F1' developed by Seminis Vegetable Seeds Company. Black polyethylene foil, $0.05 \mathrm{~mm}$ thick, and black agrotextile weighing $30 \mathrm{~g}$ per $1 \mathrm{~m}$ were used for weed control. The experiment was established as a two-factorial design in four replications. The experimental plot area was $8 \mathrm{~m}^{2}(1.6 \times 5.0 \mathrm{~m})$, with 10 plants per plot.

Seeds of all tested cultivars were sown on 13-16 May at a spacing of $0.8 \mathrm{~m}$ apart in rows and $1.0 \mathrm{~m}$ between rows, with 3 seeds per spot. After emergence the seedlings were thinned to one per spot. Crop management followed the commonly accepted recommendations for this vegetable species, including hand weed control in this treatment without mulch.

Harvest of fruits with a diameter of 3-6 cm was conducted at 2-day intervals from the 8th of July till the end of fruit setting (10th of September). The only exception was the 'Sunny Delight F1' cultivar whose fruits reached the required size one week earlier. Fruits picked up to the end of July were considered as an early yield. At the time of maximum fruit setting and development (at the end of July), samples of 15 fruits from each plot were collected for chemical analysis.
The fruits were assessed for dry matter content (drying at $105^{\circ} \mathrm{C}$ to constant weight $\left.-\mathrm{PN}-90 / \mathrm{A}-7501 / 03\right)$, total sugars (Loof Schoorl method - PN-90/A-7501/07), vitamin C (Tillmans method - PN-90/A-7501/11), carotenoids (spectrophotometric method) according to Rumińska et al. [12], total polyphenols (Folin-Ciocalateu method) according to Slinghard and Singleton [13], nitrates by the amount of $\mathrm{NO}_{3}-\mathrm{N}$ in f.w. (ion - selective method), $\mathrm{P}$ and $\mathrm{Mg}$ (colorimetric method), $\mathrm{Ca}$ and $\mathrm{K}$ (photometric method) according to Nowosielski [14].

The obtained data shown as the means for the 3-year study were subjected to statistical evaluation on the basis of analysis of variance for two factorial design. Post hoc cooperation of means between treatments was made using HSD Tukey's test at a significance level of $\alpha=0.05$.

\section{Results}

Black polyethylene foil and black agrotextile, which are mostly used as a soil cover for weed control in field vegetable crop production, caused a significant increase in marketable and early yield of scallop squash. Both these materials appeared to be almost equally suitable for mulching in production of this crop for harvest of small size fruits for processing. Irrespective of the cultivar, the increase in fruit yield obtained from the plots covered by black polyethylene foil and agrotextile was $15.8 \%$ and $13.2 \%$, respectively, over that from the non-covered control. Similar effects were noted in the case of early fruit yield (Tab. 1). The mean values for all tested cultivars did not show any significant impact of soil mulching on the chemical composition of fruits. The only exception was higher nitrate accumulation and a decrease in total sugar content in fruits from plants grown on the soil covered with black foil compared to black agrotextile or the non-covered control (Tab. 2, Tab. 3).

The cultivars of scallop squash tested in this research differed in their color, shape, and productivity. 'Sunny Delight F1', which is highly appreciated for processing and especially for pickling, has an intensive yellow skin and rather flat

Tab. 1 The effect of soil mulching on early and marketable yield of scallop squash cultivars $\left(\mathrm{t} \mathrm{ha}^{-1}\right)$.

\begin{tabular}{|c|c|c|c|c|c|c|c|c|}
\hline \multirow[b]{2}{*}{ Cultivar } & \multicolumn{4}{|c|}{ Early yield } & \multicolumn{4}{|c|}{ Marketable yield } \\
\hline & b.p.f. & b.a. & control & mean & b.p.f. & b.a. & control & mean \\
\hline Polo F1 & 3.09 & 3.61 & 2.80 & 3.17 & 11.58 & 13.55 & 10.51 & 11.88 \\
\hline Disco & 3.68 & 3.27 & 2.64 & 3.20 & 13.82 & 12.26 & 9.89 & 11.99 \\
\hline Gagat & 3.38 & 3.26 & 3.09 & 3.24 & 12.67 & 12.22 & 11.60 & 12.16 \\
\hline Okra & 4.12 & 3.91 & 3.54 & 3.86 & 15.47 & 14.65 & 13.27 & 14.46 \\
\hline Sunny Delight F1 & 4.17 & 3.99 & 3.86 & 4.01 & 15.65 & 14.96 & 14.46 & 15.02 \\
\hline Mean & 3.69 & 3.61 & 3.19 & 3.49 & 13.84 & 13.53 & 11.95 & 13.10 \\
\hline $\operatorname{LSD}_{\alpha=0.05}$ for: cultivar & & & & 0.36 & & & & 1.35 \\
\hline type of mulch & & & & 0.28 & & & & 1.04 \\
\hline mulch $\times$ cultivar & & & & n.s. & & & & n.s. \\
\hline
\end{tabular}

b.p.f. - black polyethylene foil; b.a. - black agrotextile. 
Tab. 2 The effect of soil mulching on dry matter and total sugar content of scallop squash cultivars.

\begin{tabular}{|c|c|c|c|c|c|c|c|c|}
\hline \multirow[b]{2}{*}{ Cultivar } & \multicolumn{4}{|c|}{ Dry matter (\%) } & \multicolumn{4}{|c|}{ Total sugar (\% f.m.) } \\
\hline & b.p.f. & b.a. & control & mean & b.p.f. & b.a. & control & mean \\
\hline Polo F1 & 6.41 & 6.29 & 6.44 & 6.38 & 1.54 & 1.83 & 2.00 & 1.79 \\
\hline Disco & 7.11 & 6.88 & 6.55 & 6.84 & 1.74 & 1.98 & 1.89 & 1.87 \\
\hline Gagat & 6.60 & 6.24 & 6.13 & 6.32 & 1.50 & 1.86 & 1.83 & 1.73 \\
\hline Okra & 5.64 & 5.52 & 5.79 & 5.65 & 1.69 & 2.04 & 2.01 & 1.91 \\
\hline Sunny Delight F1 & 6.89 & 6.99 & 6.69 & 6.86 & 1.55 & 1.58 & 1.58 & 1.57 \\
\hline Mean & 6.53 & 6.38 & 6.32 & 6.41 & 1.61 & 1.86 & 1.86 & 1.78 \\
\hline $\mathrm{LSD}_{\alpha=0.05}$ for: cultivar & & & & 0.52 & & & & 0.09 \\
\hline type of mulch & & & & n.s. & & & & 0.07 \\
\hline mulch $\times$ cultivar & & & & n.s. & & & & 0.16 \\
\hline
\end{tabular}

b.p.f. - black polyethylene foil; b.a. - black agrotextile.

Tab. 3 The effect of soil mulching on polyphenol and nitrate content of scallop squash cultivars.

\begin{tabular}{|c|c|c|c|c|c|c|c|c|}
\hline \multirow[b]{2}{*}{ Cultivar } & \multicolumn{4}{|c|}{ Polyphenols (mg $100 \mathrm{~g}^{-1}$ f.m.) } & \multicolumn{4}{|c|}{ Nitrates $\left(\mathrm{mg} \mathrm{NO}_{3}{ }^{-} \mathrm{kg}^{-1}\right.$ f.m.) } \\
\hline & b.p.f. & b.a. & control & mean & b.p.f. & b.a. & control & mean \\
\hline Polo F1 & 129 & 123 & 127 & 126 & 470 & 413 & 424 & 436 \\
\hline Disco & 152 & 146 & 146 & 148 & 549 & 406 & 422 & 459 \\
\hline Gagat & 85 & 85 & 75 & 82 & 580 & 508 & 551 & 546 \\
\hline Okra & 79 & 75 & 76 & 76 & 557 & 521 & 498 & 525 \\
\hline Sunny Delight F1 & 144 & 146 & 144 & 144 & 335 & 247 & 225 & 269 \\
\hline Mean & 118 & 115 & 114 & 115 & 498 & 419 & 424 & 447 \\
\hline $\operatorname{LSD}_{\alpha=0.05}$ for: cultivar & & & & 26 & & & & 77 \\
\hline type of mulch & & & & n.s. & & & & 59 \\
\hline mulch $\times$ cultivar & & & & n.s. & & & & n.s. \\
\hline
\end{tabular}

b.p.f. - black polyethylene foil; b.a. - black agrotextile.

fruit when harvested mature. The fruit shape coefficient of this cultivar, expressed as the ratio of vertical to horizontal diameter, was 0.82 . A similar fruit shape coefficient was found for 'Okra' (0.78), while a significantly lower one was observed for 'Gagat' (0.90), 'Disco' (0.86), and 'Polo F1' (0.88). 'Gagat', which is almost spherical in shape, produces dark green fruits due to the highest amounts of chlorophyll [15], while 'Disco' and 'Polo F1' are characterized by light cream colored fruits.

Irrespective of the type of soil cover, the highest early and marketable yield of fruits was produced by 'Sunny Delight F', followed by 'Okra. Both these cultivars significantly overyielded the others, e.g., 'Disco', 'Gagat', and 'Polo F1', among which the differences were negligible and not confirmed by statistical evaluation. Another advantage of the 'Sunny Delight F1' cultivar was early fruit setting, which resulted in the first fruit harvest one week earlier compared to all other cultivars tested.

The results of chemical analysis of organic and mineral compounds indicate that among the evaluated cultivars of scallop squash 'Sunny Delight F1' may be considered to be the best offer for both the fresh market and processing, because of its high biological value expressed by the highest amounts of vitamin C, phosphorus, potassium, magnesium and calcium (Tab. 4-Tab. 6). The dry matter and polyphenol content was also high and similar to 'Disco' fruits. (Tab. 2, Tab. 3). The amount of carotenoids and total sugar, however, was considerably lower, especially if compared to 'Okra'.

The other investigated cultivars did not differ significantly in their content of potassium, phosphorus, calcium and magnesium, except for 'Polo F1' whose fruits were a richer source of potassium than those of 'Okra'. The 'Okra' cultivar 
Tab. 4 The effect of soil mulching on vitamin C and carotenoid content of scallop squash cultivars.

\begin{tabular}{|c|c|c|c|c|c|c|c|c|}
\hline \multirow[b]{2}{*}{ Cultivar } & \multicolumn{4}{|c|}{ Vitamin C (mg $100 \mathrm{~g}^{-1}$ f.m.) } & \multicolumn{4}{|c|}{ Carotenoids (mg $100 \mathrm{~g}^{-1}$ d.m.) } \\
\hline & b.p.f. & b.a. & control & mean & b.p.f. & b.a. & control & mean \\
\hline Polo F1 & 23.20 & 23.81 & 20.38 & 22.46 & 0.92 & 1.09 & 0.99 & 1.00 \\
\hline Disco & 20.79 & 20.81 & 22.19 & 21.26 & 0.76 & 1.00 & 0.68 & 0.81 \\
\hline Gagat & 17.30 & 16.91 & 15.83 & 16.68 & 1.62 & 1.68 & 1.68 & 1.66 \\
\hline Okra & 16.45 & 16.05 & 14.87 & 15.79 & 1.45 & 1.84 & 1.83 & 1.70 \\
\hline Sunny Delight F1 & 28.07 & 25.23 & 26.90 & 26.73 & 0.93 & 1.01 & 0.79 & 0.91 \\
\hline Mean & 21.16 & 20.56 & 20.03 & 20.59 & 1.13 & 1.32 & 1.19 & 1.22 \\
\hline $\operatorname{LSD}_{\alpha=0.05}$ for: cultivar & & & & 2.82 & & & & 0.32 \\
\hline type of mulch & & & & n.s. & & & & n.s. \\
\hline mulch $\times$ cultivar & & & & n.s. & & & & n.s. \\
\hline
\end{tabular}

b.p.f. - black polyethylene foil; b.a. - black agrotextile.

Tab. 5 The effect of soil mulching on potassium and phosphorus content of scallop squash cultivar.

\begin{tabular}{|c|c|c|c|c|c|c|c|c|}
\hline \multirow[b]{2}{*}{ Cultivar } & \multicolumn{4}{|c|}{ Potassium (\% d.m.) } & \multicolumn{4}{|c|}{ Phosphorus (\% d.m.) } \\
\hline & b.p.f. & b.a. & control & mean & b.p.f. & b.a. & control & mean \\
\hline Polo F1 & 6.13 & 5.88 & 6.08 & 5.98 & 0.88 & 0.78 & 0.80 & 0.82 \\
\hline Disco & 4.79 & 5.75 & 5.96 & 5.50 & 0.78 & 0.84 & 0.79 & 0.80 \\
\hline Gagat & 5.25 & 5.75 & 5.50 & 5.50 & 0.68 & 0.73 & 0.68 & 0.70 \\
\hline Okra & 5.50 & 5.13 & 4.92 & 5.18 & 0.78 & 0.79 & 0.76 & 0.78 \\
\hline Sunny Delight F1 & 6.54 & 7.00 & 6.75 & 6.76 & 0.92 & 1.02 & 0.92 & 0.95 \\
\hline Mean & 5.52 & 5.90 & 5.84 & 5.75 & 0.81 & 0.83 & 0.79 & 0.81 \\
\hline $\operatorname{LSD}_{\alpha=0.05}$ for: cultivar & & & & 0.55 & & & & 0.06 \\
\hline type of mulch & & & & n.s. & & & & n.s. \\
\hline mulch $\times$ cultivar & & & & n.s. & & & & n.s. \\
\hline
\end{tabular}

b.p.f. - black polyethylene foil; b.a. - black agrotextile.

which, like 'Sunny Delight F1', has a high yield potential contained low amounts of vitamin $\mathrm{C}$ and polyphenols but exceeded all the others in its carotenoid level. A similar value of these compounds was found in fruits of the 'Gagat' cultivar.

In our study great differences in nitrate accumulation were found between tested cultivars. In 'Gagat' and 'Okra' fruits, the amount of $\mathrm{NO}_{3}-\mathrm{N}$ was twice as high as in 'Sunny Delight F1' and lower, but still significant, if compared to 'Polo F1' and 'Disco'.

\section{Discussion}

Black polyethylene foil and black agrotextile, which efficiently protect plants from weed infestation, are most often used as synthetic mulches to cover the soil in vegetable crop production. Another important advantage of soil mulching found in the study was the significant enhancement of crop yield of scallop squash. Such beneficial results may be explained by the improvement of soil microclimate conditions, especially the enhancement of temperature in the root zone. According to Wien and Mionotti [16], it is the main advantage resulting from the use of synthetic mulches, as they provide for plant growth and an increase in yield. The benefits of enhanced root zone temperature are observed in species such as tomato, pepper, cucumber, melon, and zucchini as well as scallop squash [17-21]. The data obtained in the present study, similar to the previous research with zucchini [22], indicate that the increase in early yields was not associated with the acceleration of fruiting due to the use of synthetic mulches. However, the choice of cultivars 
Tab. 6 The effect of soil mulching on calcium and magnesium content of scallop squash cultivars.

\begin{tabular}{|c|c|c|c|c|c|c|c|c|}
\hline \multirow[b]{2}{*}{ Cultivar } & \multicolumn{4}{|c|}{ Calcium (\% d.m.) } & \multicolumn{4}{|c|}{ Magnesium (\% d.m.) } \\
\hline & b.p.f. & b.a. & control & mean & b.p.f. & b.a. & control & mean \\
\hline Polo F1 & 0.45 & 0.48 & 0.46 & 0.46 & 0.34 & 0.35 & 0.35 & 0.35 \\
\hline Disco & 0.46 & 0.46 & 0.45 & 0.46 & 0.32 & 0.36 & 0.33 & 0.34 \\
\hline Gagat & 0.45 & 0.45 & 0.43 & 0.44 & 0.38 & 0.36 & 0.36 & 0.37 \\
\hline Okra & 0.46 & 0.44 & 0.45 & 0.45 & 0.36 & 0.39 & 0.35 & 0.36 \\
\hline Sunny Delight F1 & 0.51 & 0.49 & 0.48 & 0.49 & 0.39 & 0.42 & 0.37 & 0.40 \\
\hline Mean & 0.47 & 0.46 & 0.45 & 0.46 & 0.36 & 0.37 & 0.35 & 0.36 \\
\hline $\operatorname{LSD}_{\alpha=0.05}$ for: cultivar & & & & 0.03 & & & & 0.03 \\
\hline type of mulch & & & & n.s. & & & & n.s. \\
\hline mulch $\times$ cultivar & & & & n.s. & & & & n.s. \\
\hline
\end{tabular}

b.p.f. - black polyethylene foil; b.a. - black agrotextile.

had a higher impact on fruit yield of scallop squash; among them, the best results were obtained from 'Sunny Delight F1', highly appreciated for its yellow color skin, and from 'Okra'. A lower yield potential, similar for these cultivars, was found for 'Disco,' 'Gagat' and 'Polo F1' and this is in agreement with the results obtained in the research conducted by Grzeszczuk [23].

Scallop squash is commonly recognized as a rich source of biologically active components, especially vitamin C, carotenoids (Tab. 4), polyphenols (Tab. 3), and minerals (Tab. 5, Tab. 6) [2,7]. However, the nutritional value of fruits is highly dependent on the stage of maturity at harvest and can also be influenced by the cultivar. There are many reports indicating that, like in zucchini, fruits harvested at early stages of development, when they have a diameter ranging 3-6 cm, have the greatest nutritional value due to higher amounts of protein, carotenoids, ascorbic acid and macronutrients, but lower nitrate accumulation [7,21,24,25]. Furthermore, small size fruits are more delicate in both texture and flavor, and for this reason they are preferred by consumers and the food industry. As proven in this study, the nutritional value of such fruits was significantly affected by the cultivars, among which the highest content of the most valuable components was found in 'Sunny Delight F1'. Like in the study conducted by Grzeszczuk [2], the cultivars 'Disco', 'Gagat' and 'Polo F1' appeared to be a rich source of minerals, showing no significant differences in the content of particular macronutrients. The impact of soil mulching on the nutritional value of fruits was negligible and this finding

\section{Acknowledgments}

Research funded by the Faculty of Life Sciences and Technology, Wrocław University of Environmental and Life Sciences.

\section{Authors' contributions}

The following declarations about authors' contributions to the research have been made: research designing: $\mathrm{EK}$; conducting experiment: $\mathrm{AB}$; writing the manuscript: EK. is in agreement with the studies previously conducted on zucchini [22] and cucumber [20].

A great advantage of scallop squash fruits, especially if harvested at early stages of maturity, is the low content of nitrates which, depending on the type of material used for mulching and the cultivar, ranged between 225 and 580 $\mathrm{mg} \mathrm{kg}^{-1}$ f.w. A low level of nitrate accumulation in fruits of different species from the Cucurbitaceae family, including pumpkin, winter squashes, zucchini and scallop squash, was reported by Danilčenko [8]. Higher, but still acceptable, levels of $550 \mathrm{mg} \mathrm{kg}^{-1}$ f.w. in small size fruits and $774 \mathrm{mg} \mathrm{kg}^{-1}$ f.w. in fully matured ones were determined by Grzeszczuk [26]. Similar relations between the size of fruits and the content of nitrates were observed in zucchini [27].

\section{Conclusions}

Among the cultivars tested, 'Sunny Delight F1' showed the highest yield potential, earliness of fruit setting and nutritional value expressed by the content of dry matter, vitamin C, polyphenols, calcium and magnesium. Low nitrate accumulation is also an advantage.

A yield of 'Okra' plants was similar to 'Sunny Delight F1', however 'Okra' fruits contained higher amounts of sugar and carotenoids, but a lower content of vitamin C and polyphenols.

Soil mulching increased marketable and total yield of scallop squash and had no impact on fruit chemical composition.

\section{Competing interests}

No competing interests have been declared.

\section{References}

1. Gajewski M. Badania nad przechowywaniem cukinii i patisonów. In: Conference proceedings "Nowe technologie a jakość plonu warzyw"; 1995 Jun 20-21; Wrocław, Polska. Wrocław: Wydawnictwo Akademii Rolniczej we Wrocławiu; 1995. p. 127-131. 
2. Grzeszczuk M. Zawartość składników mineralnych w owocach wybranych odmian patisona. J Elem. 2003;8(2):57-63.

3. Kołota E. Balbierz A. Effect of nitrogen fertilization on pre-and postharvest quality of scallop squash harvested at different stages of fruit maturity. In: 3rd International conference proceedings "Effects of pre-and post-harvest factors on health promoting components and quality of horticultural commodities"; 2014 Mar 23-24; Skierniewice, Poland. Skierniewice: Research Institute of Horticulture in Skierniewice; 2014. p. 56.

4. Grzeszczuk M. Biological value of patisson (Cucurbita pepo L var. patissonina) flowers. In: Conference proceedings "Quality of horticultural production”; 2007 May 30-31; Lednice, Czech Republic. Brno: Mendel University in Brno; 2007. p. 33-39.

5. Rubatzky VE, Yamaguchi M. World vegetables. Principles, production, and nutritive values. 2nd ed. New York, NY: Champan \& Hall Press; 1997.

6. Lorenz OA. Maynard DN. Knott's handbook for vegetable growers. 3rd ed. New York, NY: John Wiley \& Sons Press; 1988.

7. Gajc-Wolska J, Skąpski H. Evaluation of various methods of production of zucchini and scallop. Acta Hortic. 1994;371:183-187. http:// dx.doi.org/10.17660/ActaHortic.1994.371.22

8. Danilčenko $H$. The research on biochemical composition, culinary values and usability for processing of pumpkin family vegetables. Rocz Akad Rol Pozn Ogrodn. 2000;31(2):245-252.

9. Grzeszczuk M, Falkowski J. The estimation of mineral components in different stages of the ripening of patisson fruits. J Elem. 2002;7(3):196-203.

10. Grzeszczuk M, Falkowski J, Jakubowska B. The estimation of fruit quality of three local patisson cultivars. Acta Sci Pol Hortorum Cultus. 2003;2(1):117-123.

11. Centralny Ośrodek Badania Odmian Roślin Uprawnych. Polish National List of Vegetable Plant Varieties. Słupia Wielka: Centralny Ośrodek Badania Odmian Roślin Uprawnych; 2015.

12. Rumińska A, Suchorska K, Węglarz Z. Rośliny lecznicze i specjalne. Warszawa: SGGW-AR; 1985.

13. Slinghart K, Singleton VL. Total phenol analysis: automation and comparison with manual method. Am J Enol Viticult. 1977;28:49-55.

14. Nowosielski O. Methods of evolution for plant nutrients requirement. Warszawa: Powszechne Wydawnictwo Rolnicze i Leśne; 1974.

15. Grzeszczuk M. Chemical composition and storage ability of three patisson cultivars. Spontaneous and induced variation for the genetic improvement of horticultural crops. Bydgoszcz: Uniwersytet Technologiczno-Przyrodniczy; 2007.

16. Wien HC, Mionotti PL. Growth, yield and nutrient uptake of transplanted fresh-market tomatoes as affected by plastic mulch and initial nitrogen rate. J Am Soc Hortic Sci. 1987;112:759-763.

17. Kaniszewski S. Reakcja pomidora na kroplowe nawadnianie oraz mulczowanie folią i włókniną polipropylenową. Biul Warz. 1994;41:29-38.

18. Brown JE, Channell-Butcher C. Black plastic mulch and drip irrigation affect growth and performance of bell pepper. J Veg Crop Prod. 2001;7(2):109-112. http://dx.doi.org/10.1300/J068v07n02_11

19. Gordon GG, Foshee WG III, Reed ST, Brown JE, Vinson E, Woods FM. Plastic mulches and row covers on growth and production of summer squash. Int J Veg Sci. 2008;14(4):322-338. http://dx.doi. org/10.1080/19315260802215830

20. Spiżewski T, Frąszczak B, Kałużewicz A, Krzesiński W, Lisiecka J. The effect of black polyethylene mulch on yield of field-grown cucumber. Acta Sci Pol Hortorum Cultus. 2010;9(3):221-229.

21. Kołota E. Adamczewska-Sowińska K. Application of synthetic mulches and flat covers with perforated foil and agrotextile in zucchini. Acta Sci Pol Hortorum Cultus. 2011;10(4):79-189.

22. Kołota E. Słociak A. The effects of the term of weed removal and soil mulching on yield and chemical composition of zucchini fruits. Veg Crop Res Bull. 2003;59:83-89.

23. Grzeszczuk M. Chemical composition and storage ability of three patisson cultivars. In: Nowaczyk P, editor. Spontaneous and induced variation for the genetic improvement of horticultural crops. Bydgoszcz: University of Technology and Life Science; 2007. p. 137-143.

24. Gajewski M, Rosłon W. Changes in the content of polyphenolic acids and carotenoids in zucchini squash fruits (Cucurbita pepo var. giromontina Alef) in relation to the maturity stage and storage conditions. Folia Hortic. 2002;14(1):155-162

25. Kołota E. Słociak A. Nitrogen fertilization of zucchini harvested at different stages of fruit development. Acta Hortic. 2006;700:121-124. http://dx.doi.org/10.17660/ActaHortic.2006.700.17

26. Grzeszczuk M. Czynniki kształtujące jakość i trwałość pozbiorczą owoców patisona (Cucurbiata pepo L. var. patisonina Greb. f. radiata Nois.). Szczecin: Zachodniopomorski Uniwersytet Technologiczny w Szczecinie; 2009

27. Biesiada A, Kołota E, Adamczewska-Sowińska K. The effect of maturity stage on nutritional value of leek, zucchini and kohlrabi. Veg Crop Res Bull. 2007;66:39-45. http://dx.doi.org/10.2478/v10032-007-0006-8

\section{Plonowanie i jakość owoców różnych odmian patisona (Cucurbita pepo L. var. patissonina Greb. f. radiata Nois.) uprawianych dla przetwórstwa}

\section{Streszczenie}

Owoce patisona (Cucurbita pepo L. var. patissonina Greb. f. radiata Nois. Cucurbitaceae) mogą być zbierane w różnych fazach dojrzałości. Najwyższą wartość biologiczną wykazują owoce małe przeznaczone na potrzeby rynku świeżego oraz dla przetwórstwa. W doświadczeniu porównano plonowanie 5 odmian patisona ('Polo F1', 'Disco', 'Gagat', 'Okra', 'Sunny Delight F1') uprawianych na glebie ściółkowanej (czarna folia, czarna agrowłóknina) oraz bez ściółkowania. Owoce były zbierane, gdy ich średnica osiągała wielkość 3-6 cm. 3-letnie badania wykazały, że najbardziej wydajną dla przetwórstwa odmianą dającą najwcześniejszy plon jest odmiana 'Sunny Delight F1', bardzo atrakcyjna dla konsumenta ze względu na żółty kolor skórki. Uzyskane wyniki wskazują, że odmiana ta posiada wysoką wartość odżywczą wyrażającą się najwyższą zawartością suchej masy, witaminy $\mathrm{C}$, polifenoli i związków mineralnych ( $\mathrm{K}, \mathrm{P}, \mathrm{Ca}, \mathrm{Mg}$ ), oraz najmniejszą tendencją do akumulacji azotanów. Spośród pozostałych odmian 'Okra' wydała wysoki plon i podobnie jak odmiana 'Gagat’ była bogatym źródłem karotenoidów, a 'Disco' - polifenoli. Zarówno czarna folia jak i czarna agrowłóknina okazały się cennym materiałem do ściółkowania gleby. Zastosowane ściółki korzystnie wpłynęły na plonowania roślin, nie miały wpływu na skład chemiczny owoców patisona. 